\title{
Pressure measurement devices: from technical assessment to clinical performance
}

\author{
Claudia Giacomozzi ${ }^{* *}$, Moreno D'Amico ${ }^{2}$, Piero Roncoletta ${ }^{2}$ \\ From 3rd Congress of the International Foot and Ankle Biomechanics Community \\ Sydney, Australia. 11-13 April 2012
}

\section{Background}

Technical assessment of pressure measurement devices (PMDs) should guarantee for their appropriate use in the clinics. The study aims at proving the validity of the assessment methodology ISS proposed [1], and at quantifying the impact of PMD performance on clinical assessment.

\section{Materials and methods}

Three commercial PMDs were first assessed and then compared during barefoot walking: PMDa and PMDb - resistive technology, 1 sens $/ \mathrm{cm}^{2}$ - were assessed onsite, while PMDc - capacitive technology, $4 \mathrm{sens} / \mathrm{cm}^{2}$ was tested on-the-bench and on-site [1]. The PMDs were aligned on the floor to capture successive at-regimen steps of the left foot of one trained volunteer; 10 complete steps were acquired in both directions for each PMD; data were temporally normalised and averaged; main kinetic parameters were extracted.

Table 1 Results from the on-the-bench and on-site assessment, and with respect to some clinically relevant parameters.

\begin{tabular}{|c|c|c|c|c|c|}
\hline $\begin{array}{l}\text { PMD } \\
\text { under test }\end{array}$ & $\begin{array}{l}\text { ISS Full technical } \\
\text { assessment }\end{array}$ & $\begin{array}{l}\text { ISS On-site partial } \\
\text { assessment }\end{array}$ & $\begin{array}{l}\text { "gait" assessment: Peak } \\
\text { pressure }(\mathrm{kPa})\end{array}$ & $\begin{array}{l}\text { "gait" assessment: Mean } \\
\text { pressure }(\mathrm{kPa}))\end{array}$ & $\begin{array}{l}\text { "gait" assessment } \\
\text { Integral }\left(\mathrm{kPa}^{*} \mathbf{s}\right)\end{array}$ \\
\hline a & not performed & error $>10 \%$ at $250 \mathrm{kPa}$ & $100(4)^{* *}$ & $80(2)^{* *}$ & $39(2)^{* *}$ \\
\hline b & not performed & error $<5 \%$ at $250 \mathrm{kPa}$ & $266(12)^{*}$ & $191(8)^{*}$ & $85(9)^{*}$ \\
\hline C & $\begin{array}{l}\text { accuracy error }<5 \% \text { up } \\
\text { to } 1200 \mathrm{kPa}\end{array}$ & error $<5 \%$ at $250 \mathrm{kPa}$ & $744(137)$ & $367(17)$ & $152(23)$ \\
\hline
\end{tabular}

* statistically different from PMDc corresponding data ( $\mathrm{p}<0.05$, also verified with respect to the $\pm 5 \%$ maximum error); ${ }^{*}$ statistically different from PMDb and PMDc corresponding data $(p<0.05$, also verified with respect to the $\pm 5 \%$ maximum error)

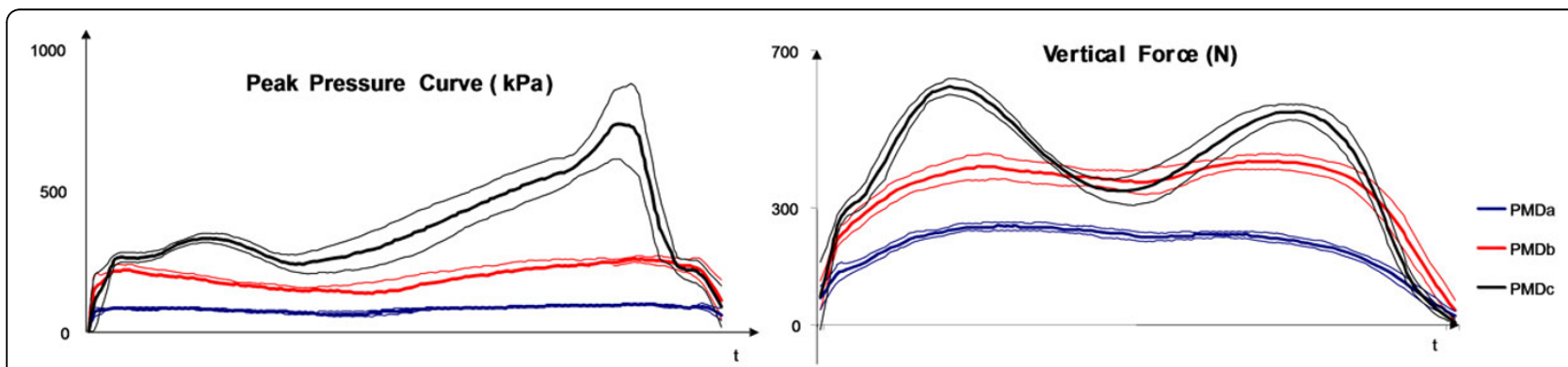

Figure 1 Peak Pressure and Vertical Force curves obtained by the three tested PMDs; mean curve \pm sd curve averaged over 10 left steps.

\footnotetext{
* Correspondence: c_giacomozzi@yahoo.com

'Dept. Of Technology and Health, Italian National Institute of Health (ISS),

Rome, Italy

Full list of author information is available at the end of the article
} 


\section{Results}

Preliminary results (Table 1 and Figure 1): i) PMDc resulted accurate and was used as a reference; ii) PMDa was found inaccurate on-site and delivered unreliable gait data; iii) PMDb was found accurate on-site but performed significantly worse than PMDc during gait.

\section{Conclusions}

To conclude: i) on-site assessment up to $250 \mathrm{kPa}$ proved to be necessary but not sufficient to guarantee for a good PMD performance during gait; ii) a thorough onthe-bench assessment is effective and recommended; iii) use of PMDb data might be misleading in research and risky in the clinics. The study is going on with the comparison among other commercial PMDs and under a wide range of testing conditions.

\section{Author details}

${ }^{1}$ Dept. Of Technology and Health, Italian National Institute of Health (ISS)

Rome, Italy. ${ }^{2}$ Bioengineering and Biomedicine Company srl, Pescara, Italy.

Published: 10 April 2012

\section{References}

1. Giacomozzi C: Hardware performance assessment recommendations and tools for baropodometric sensor systems. Ann Ist Super Sanita 2010, 46:158-167.

2. Giacomozzi C: Potentialities and criticalities of Plantar Pressure Measurements in the Study of Foot Biomechanics: Devices,

Methodologies and Applications. In Biomechanics in Applications.. 1 edition. Intech;Vaclav Klika 2011:249-274.

\section{Submit your next manuscript to BioMed Central} and take full advantage of:

- Convenient online submission

- Thorough peer review

- No space constraints or color figure charges

- Immediate publication on acceptance

- Inclusion in PubMed, CAS, Scopus and Google Scholar

- Research which is freely available for redistribution

Submit your manuscript at www.biomedcentral.com/submit 